\title{
IMPORTANCE OF DUAL CAREER IN THE DEVELOPMENT OF SPORTS SCHOOLS IN VIDZEME REGION
}

\author{
Rihards Parandjuks \\ University of Latvia, Latvia \\ Ilvis Ābeḷkalns \\ University of Latvia, Latvia
}

\begin{abstract}
The main objective of this research is to analyse the situation regarding the development of dual education in Vidzeme regional sports schools. The paper consists of an introduction, the results of the research and their analysis, a discussion and conclusions.

The introduction examines the structure of the basic premise of dual education and examples from European countries, responsibilities and competences of educational institution management.

The research is based on surveys of 9 major representatives of Vidzeme sports schools regarding the current state of dual education and plans for the future as well as 73 athletes of sports schools to learn about their experience. The data are analysed, followed by a discussion and conclusions.
\end{abstract}

Keywords: dual career, education management, Latvian sports schools, sports.

\section{Introduction}

Sports has become an integral part of modern society promoting socialization and communication. Over time the definition of sports has evolved to a broad and encompassing term. The main document establishing the fundamental principles of sports is the Olympic Charter that emphasizes the importance of harmony of the body and mind. The European Sports Charter is also significant and establishes the principles of tolerance and fair play. The aim of the Charter is to encourage continuous 
individual progress and enhancement of interaction between the emotional and physical state.

Dual careers have become a relevant matter in the European Union as they are one of the main tools that can improve social life. The authors believe the fusion of sports and education to be a productive way of ensuring gradual development of a personality in Latvia. Another important aspect adding to the relevance of this research is the current situation of dual careers in Latvia as the current system has areas in need of further development. Several officials, representatives of sports schools and academics have referred to the issue of high-profile athletes experiencing difficulties successfully managing sports and academics. These difficulties persist throughout primary, secondary school and university.

The authors wish to outline the possible modes of cooperation between sports schools and secondary schools. The government classifies sports schools as equivalents to vocational education institutions. The definition of a sports school is an institution established by the state, municipality, legal entity or private individual with the aim to implement programmes of sports education. Students enrolled in these educational institutions should receive academic and professional support as they merge two vital components of their development, namely, academic education and professional sports.

The next stage in the development of a dual career system is cooperation with higher education institutions. The system of sports education in Latvia ensures a high level of preparation of young athletes until graduation of secondary school. This is mediated by local sports schools that to the extent possible provide their students with the necessary equipment and the opportunities to compete. A crucial aspect is prescribed by the regulations of the Cabinet of Ministers that grant the opportunity for athletes to continue their chosen education until the age of 25. However, the main reason for opting out of this opportunity is the lack of suitable conditions, for example, the lack of appropriate infrastructure central to successful management of sports and academics (Sports Law, 2002).

The alternative solution put forward by the authors is the possible cooperation between sports schools and higher education institutions. Conclusion of mutual agreements could provide the necessary framework for further development of a dual career system. The tasks of sports schools would be to prepare young students capable of joining the students' sports communities, whereas the tasks of higher education institutions would be to provide the academic environment for athletes warranting the necessary social guarantees. 
As a result, upon graduation from secondary school, young athletes would have additional motivation to continue their professional development in higher education institutions.

\section{Methodology}

Objectives. To research and analyse the importance of dual careers in the development of sports schools in Vidzeme region (Latvian Northeast region) as well as conclude cooperation agreements between sports schools and educational institutions. Location of research - central city on Vidzeme - Cēsis.

Research. The authors carried out quantitative research using survey research design that included 80 athletes currently enrolled in one of the sports schools in Vidzeme region participating in this research. 73 respondents provided answers. The average age of the respondents was 15 to 19 . The athletes were chosen based on the current self-evaluation reports of these sports schools and availability. They were given a set of 15 statements with the possible answers of completely agree, agree, disagree, completely disagree. The data were collected and analysed using the SPSS software of statistical analysis and Microsoft Excel.

Kendall's coefficient of concordance was used. It is a method of statistical analysis that is used to determine the concordance among variables. The value of the coefficient is between -1 and 1 , the closer it is to either of these values, the higher the concordance among variables. If it is closer to zero, then the concordance is minor (McClave2, 2003).

Concordance among variables is considered statistically significant, if the corresponding p-value is lower than the determined significance level. Correlation significance is evaluated at $1 \%$ and $5 \%$ levels, sometimes also at the $10 \%$ level. For example, if the p-value is less than 0.05 , then the corresponding correlation is considered statistically significant at the $5 \%$ level.

\section{Results}

The first seven statements of the survey were designed to acquire the opinions of respondents in regards to possibilities of a dual career in the setting of middle and secondary school. The resulting correlations point towards important trends.

Between statements two and five a p-value of 0.00 can be observed, which is statistically significant. The former statement asserts that sports can easily be balanced with academic studies, whereas the latter statement claims that coaches are understanding in regards to academic studies. The 
Table 1. Correlations among responses

\begin{tabular}{|c|c|c|c|c|c|c|c|c|c|}
\hline & & & 1. Assertion & 2. Assertion & 3. Assertion & 4. Assertion & 5. Assertion & 6. Assertion & 7. Assertion \\
\hline \multirow[t]{21}{*}{ Kendall's tau_b } & \multirow[t]{3}{*}{ 1. Assertion } & Correlation Coefficient & 1,000 &, $354^{* *}$ & ,116 & ,070 & ,137 &,- 083 & ,138 \\
\hline & & Sig. (2-tailed) & &, 001 & ,281 &, 517 & ,204 & ,446 & ,196 \\
\hline & & $\mathrm{N}$ & 73 & 73 & 73 & 73 & 73 & 73 & 73 \\
\hline & \multirow[t]{3}{*}{ 2. Assertion } & Correlation Coefficient &, $354^{* *}$ & 1,000 &, $514^{* *}$ & ,232* &, $436^{* *}$ &, $279^{* *}$ & $288^{* \prime}$ \\
\hline & & Sig. (2-tailed) &, 001 & &, 000 & ,029 &, 000 &, 009 &, 006 \\
\hline & & $\mathrm{N}$ & 73 & 73 & 73 & 73 & 73 & 73 & 73 \\
\hline & \multirow[t]{3}{*}{ 3. Assertion } & Correlation Coefficient & ,116 &, $514^{* *}$ & 1,000 &, $332^{* *}$ &, 382 &, $268^{*}$ &, $243^{*}$ \\
\hline & & Sig. (2-tailed) & ,281 &, 000 & &, 002 &, 000 & ,012 &, 021 \\
\hline & & $\mathrm{N}$ & 73 & 73 & 73 & 73 & 73 & 73 & 73 \\
\hline & \multirow[t]{3}{*}{ 4. Assertion } & Correlation Coefficient & ,070 &, $232^{*}$ & ,332* & 1,000 & ,135 &, $255^{*}$ & , 184 \\
\hline & & Sig. (2-tailed) &, 517 &, 029 &, 002 & & ,204 &, 017 &, 081 \\
\hline & & $\mathrm{N}$ & 73 & 73 & 73 & 73 & 73 & 73 & 73 \\
\hline & \multirow[t]{3}{*}{ 5. Assertion } & Correlation Coefficient & , 137 &, $436^{* *}$ &, $382^{* *}$ & ,135 & 1,000 &, $584^{* *}$ & , 154 \\
\hline & & Sig. (2-tailed) & ,204 &, 000 &, 000 & ,204 & &, 000 & , 142 \\
\hline & & $\mathrm{N}$ & 73 & 73 & 73 & 73 & 73 & 73 & 73 \\
\hline & \multirow[t]{3}{*}{ 6. Assertion } & Correlation Coefficient &,- 083 &, $279^{\prime \prime}$ & $268^{*}$ & $255^{*}$ &, $584^{*}$ & 1,000 & $247^{*}$ \\
\hline & & Sig. (2-tailed) & ,446 &, 009 &, 012 &, 017 &, 000 & &, 019 \\
\hline & & $\mathrm{N}$ & 73 & 73 & 73 & 73 & 73 & 73 & 73 \\
\hline & \multirow[t]{3}{*}{ 7. Assertion } & Correlation Coefficient & 138 &, $288^{* *}$ & $243^{*}$ & , 184 & 154 & $247^{*}$ & 1,000 \\
\hline & & Sig. (2-tailed) & , 196 &, 006 &, 021 &, 081 & ,142 & 019 & \\
\hline & & $\mathrm{N}$ & 73 & 73 & 73 & 73 & 73 & 73 & 73 \\
\hline
\end{tabular}

1. Assertion - I learned studies without difficulties

4. Assertion - Sports school interested about education

11. Assertion - Sports school interested about dual career in university

12. Assertion - I believe that sports schools need to make sure that athletes turn in to dual career process

13. Assertion - I also plan to focus on dual career in study phase

Other assertions are described in the text

correlation is 0.436 . This signifies the impact of coaches on development of dual careers. If a sports teacher comprehends and emphasizes the importance of academic education in the daily lives of athletes, students are encouraged and have better chances of successfully balancing their studies and professional sports.

Academic secondary education institutions have an effect on development of the dual career system. This is displayed by the p-value of 0.00 between the second and third statements, the correlation is 0.514 . The statements mention the support of the academic education institution for young athletes. Similar to the correlation described previously, the respondents appreciate the support of the academic education institution, in this particular situation the secondary schools attended by the respondents. If teachers support the extracurricular activities of these students and look for compromise and cooperation, it can be considered as a way of improving and developing dual careers. (Golsorhi, 2015).

The second part of the survey consisted of statements targeted towards the potential of a dual career after secondary school. A statistically significant correlation can be observed between the final statements $(14,15)$. The p-value of 0.00 is identical to the aforementioned 
correlations, the correlation is 0.462 . The statements ask about future plans of representing the sports school after finishing secondary school as well as the overall assessment of the functionality and possibilities of dual careers in sports schools. The correlation shows the desire of young athletes to continue their career in professional sports after secondary school, however in reality the outcome is the opposite. Bearing this in mind, the replies for the next statement gravitate towards the negative spectrum of answers as respondents do not see opportunities to be able to continue representing their sports school during studies in universities. The authors believe that this could be explained by the experience of dual careers by previous graduates of these sports schools. Therefore, current students view their future associations with sports schools in a negative way.

Table 2. Correlations among responses

\begin{tabular}{|c|c|c|c|c|c|c|c|c|c|c|c|c|c|c|c|c|}
\hline 11. Assertion & $\begin{array}{l}\text { Correlation Coefficient } \\
\text { Sig. (2-tailed) } \\
\mathrm{N}\end{array}$ & $\begin{array}{r}, 067 \\
, 539 \\
73\end{array}$ & $\begin{array}{r}, 121 \\
, 256 \\
73\end{array}$ & $\begin{array}{r}, 209^{\star} \\
.050 \\
73\end{array}$ & $\begin{array}{r}, 312 " \\
, 004 \\
73\end{array}$ & $\begin{array}{r}, 143 \\
, 180 \\
73\end{array}$ & $\begin{array}{r}.161 \\
.134 \\
73\end{array}$ & \begin{tabular}{r|}
, $528 *$ \\
, 000 \\
73
\end{tabular} & $\begin{array}{r}, 277^{* *} \\
, 010 \\
73\end{array}$ & $\begin{array}{r}, 100 \\
, 349 \\
73\end{array}$ & $\begin{array}{r}, 123 \\
, 254 \\
73\end{array}$ & 1,000 & $\begin{array}{r}.369 * \\
, 001 \\
73\end{array}$ & $\begin{array}{r}, 027 \\
, 804 \\
73\end{array}$ & $\begin{array}{r}.149 \\
.163 \\
73\end{array}$ & $\begin{array}{r}, 031 \\
, 763 \\
73\end{array}$ \\
\hline 12. Assertion & $\begin{array}{l}\text { Correlation Coefficient } \\
\text { Sig. (2-tailed) } \\
\text { N }\end{array}$ & $\begin{array}{r}-, 010 \\
, 927 \\
73\end{array}$ & $\begin{array}{r}.289^{* *} \\
, 006 \\
73\end{array}$ & $\begin{array}{r}, 298 * \\
, 005 \\
73\end{array}$ & $\begin{array}{r}.020 \\
.851 \\
73\end{array}$ & $\begin{array}{r}, 222 \\
73\end{array}$ & $\begin{array}{r}.207 \\
.051 \\
73\end{array}$ & $\begin{array}{r}, 281^{*} \\
, 007 \\
73\end{array}$ & $\begin{array}{r}, 318^{* *} \\
, 003 \\
73\end{array}$ & $\begin{array}{r}, 049 \\
, 644 \\
73\end{array}$ & $\begin{array}{r}, 148 \\
, 163 \\
73\end{array}$ & $\begin{array}{r}, 369 \\
, 001 \\
73\end{array}$ & 1,000 & $\begin{array}{r}, 362 \\
, 001 \\
73\end{array}$ & $\begin{array}{r}.108 \\
.308 \\
73\end{array}$ & $\begin{array}{r}, 101 \\
, 329 \\
73\end{array}$ \\
\hline 13. Assertion & $\begin{array}{l}\text { Correlation Coefficient } \\
\text { Sig. (2-tailed) } \\
\text { N }\end{array}$ & $\begin{array}{r}-, 040 \\
, 714 \\
73\end{array}$ & $\begin{array}{r}, 153 \\
, 151 \\
73\end{array}$ & $\begin{array}{r}.177 \\
, 096 \\
73\end{array}$ & $\begin{array}{r}.071 \\
.506 \\
73\end{array}$ & $\begin{array}{r}541 \\
73\end{array}$ & $\begin{array}{r}.081 \\
.449 \\
73\end{array}$ & $\begin{array}{r}.056 \\
.599 \\
73\end{array}$ & $\begin{array}{r}, 209 \\
, 050 \\
73\end{array}$ & $\begin{array}{r}, 071 \\
, 505 \\
73\end{array}$ & $\begin{array}{r}192 \\
, 072 \\
73\end{array}$ & $\begin{array}{r}.027 \\
, 804 \\
73\end{array}$ & $\begin{array}{r}.362 " \\
.001 \\
73\end{array}$ & 1,000 & $\begin{array}{r}.106 \\
.320 \\
73\end{array}$ & $\begin{array}{r}, 116 \\
73\end{array}$ \\
\hline 14. Assertion & $\begin{array}{l}\text { Correlation Coefficient } \\
\text { Sig. (2-tailed) } \\
\mathrm{N}\end{array}$ & $\begin{array}{r}, 260^{*} \\
, 016 \\
73\end{array}$ & $\begin{array}{r}, 197 \\
, 063 \\
73\end{array}$ & $\begin{array}{r}, 235^{*} \\
.026 \\
73\end{array}$ & $\begin{array}{r}.086 \\
.418 \\
73\end{array}$ & $\begin{array}{r}, 047 \\
, 658 \\
73\end{array}$ & $\begin{array}{r}.069 \\
.516 \\
73\end{array}$ & $\begin{array}{r}-, 001 \\
, 995 \\
73\end{array}$ & $\begin{array}{r}-, 116 \\
, 272 \\
73\end{array}$ & $\begin{array}{r}, 347^{*} \\
, 001 \\
73\end{array}$ & $\begin{array}{r}, 803 * \\
, 000 \\
73\end{array}$ & $\begin{array}{r}, 149 \\
, 163 \\
73\end{array}$ & \begin{tabular}{r|r}
, 108 \\
308 \\
73
\end{tabular} & $\begin{array}{r}, 106 \\
, 320 \\
73\end{array}$ & 1,000 & $\begin{array}{r}.462 \\
, 000 \\
73\end{array}$ \\
\hline 15. Assertion & $\begin{array}{l}\text { Correlation Coefficient } \\
\text { Sig. (2-tailed) } \\
\mathrm{N}\end{array}$ & $\begin{array}{r}, 171 \\
, 104 \\
73\end{array}$ & $\begin{array}{r}.126 \\
.223 \\
73\end{array}$ & $\begin{array}{r}, 206^{*} \\
.046 \\
73\end{array}$ & $\begin{array}{r}921 \\
73\end{array}$ & $\begin{array}{r}, 575 \\
73\end{array}$ & $\begin{array}{r}.084 \\
.420 \\
73\end{array}$ & $\begin{array}{r}830 \\
73\end{array}$ & $\begin{array}{r}, 366 \\
73\end{array}$ & $\begin{array}{r}.360 * \\
.001 \\
73\end{array}$ & $\begin{array}{r}, 484 \\
, 000 \\
73\end{array}$ & $\begin{array}{r}, 031 \\
, 763 \\
73\end{array}$ & $\begin{array}{r}.101 \\
.329 \\
73\end{array}$ & $\begin{array}{r}, 164 \\
, 116 \\
73\end{array}$ & $\left(\begin{array}{r}.462 " \\
.000 \\
73\end{array}\right.$ & 1,000 \\
\hline
\end{tabular}

All data described in the previous sections have a 1\% significance level representing strong correlations.

Correlation between statements 11 and 12 is statistically significant as the p-value is 0.01 which includes it in the $5 \%$ significance level. Correlation between both statements is 0.69 . The first statement asserts the initiatives of sports schools to motivate the individual respondents to continue their academic education in universities. The second statement enquired about the respondents' opinions in regards to the necessity of sports schools to stress the importance of higher education. The correlation shows that young athletes wish to receive more information and motivation from sports schools regarding higher education (Geranisova, 2015). In reality, however, they have not received such information. The authors suspect that sports schools may not devote enough attention to encouraging the development of dual careers. 
The authors wish to draw attention to the statements that directly present the inclination of sports schools to focus on dual careers. The fourth statement of the survey included the efforts of sports schools to show concern regarding the academic performance of their students.

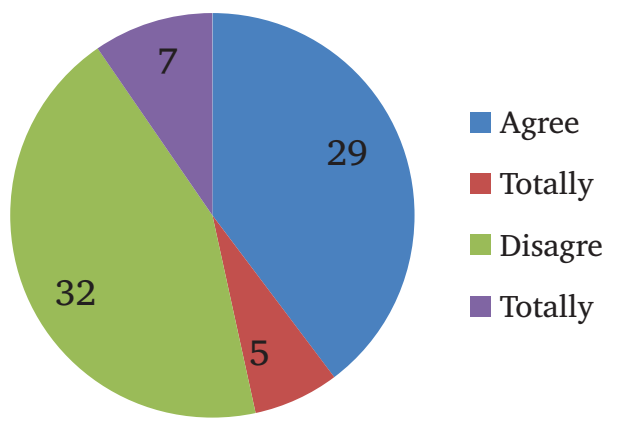

Figure 1. Interest of sports schools in the academic performance of students

Analysis of respondents' opinions regarding the interest of sports schools about their academic performance (see Figure 1) reveals that the results can be assessed as partly positive. Although a significant part of respondents (n-29) stated that their sports school is interested in their academic performance, most respondents (n-32) marked disagree as their answer to this statement. The authors presume that these statistics are influenced by the general position of the executive management of sports schools as well as that of individual coaches and their approach towards their students' academic performance.

The answers of completely agree and disagree were the least popular among respondents (n-5) and (n-7), respectively.

The authors would also like to address the $11^{\text {th }}$ statement. It is concerned with the activity and initiatives of sports schools in the development of dual careers.

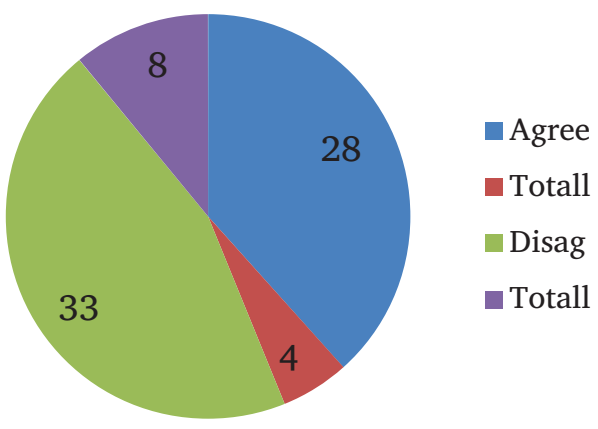

Figure 2. Recommendations of sports schools to obtain higher education while continuing professional sport 
The results represent a similar situation to the one in regards to cooperation with secondary schools. Most respondents (n-33) point towards a negative trend as no activities have been established to support students in considering and choosing a higher education institution while continuing pursuing professional sports. Eight respondents (n-8) were even more strict stating that they completely disagree. Conversely, (n-28) respondents had noticed such initiatives in their sports schools and (n-4) respondents stated that they completely agree. Analysis of international literature confirms the trend of local sports schools struggling to adapt to new tendencies and innovations or being late in their implementation. Thus, the development and promotion of dual careers is not at a satisfactory level (European Union, 2013).

Assessment of dual careers in Europe and consulting with local officials regarding the situation in Latvia, facilitated the authors in development of a real example how a local sports school can cooperate with a secondary school. The cooperation was established between Cēsis Sports School and Cēsis Secondary School which are in Northeast Latvia. Implementation of this cooperation is planned for academic year 2019/2020.

This cooperation model created by the authors is based on collecting data, experience and trends in dual careers across Europe taking into account the local setting and possibilities in Latvia. The cooperation model plans to introduce a health and sports profile. It has already been elucidated by a Norwegian researcher (Kristiansen, 2017) that during the study process, it is vital that students have swimming lessons, physical education and also skiing to the extent possible. A similar presumption has also been put forward by a British researcher (Lee, 2017) underlining the importance of development of personality and its stimulation by the educational institution.

Examination of conclusions made by different researchers in the context of what is required for a dual career and adapting these requirements to coincide with the actual capabilities, the authors propose that the students enrolled in the health and sports profile have:

- An additional third physical education class per week;

- Physiotherapy classes;

- Swimming lessons under coach supervision;

- Skiing lessons.

The health and sports profile will be implemented from grades 5 to 7 , the mandatory curriculum will remain unchanged, however it will be adjusted to include the extra sports activities. Due to the load on infrastructure, the physical education classes are planned in the mornings. Students enrolled in the health and sports profile will have to conform with the academic requirements regarding the average grade (minimum of 6.0) as well as all semester/year grades which will have to be at least 4 in every subject. 
Students incapable of attaining this level of academic performance will not be permitted to continue their studies in the health and sports profile. The project will receive financial support from the Cēsis Municipality.

The other cooperation agreement involves a more problematic area of the sports system, that is, university students and sports. During studies in higher education institutions, most young athletes stop pursuing their career in sports, although their potential has not been reached. The reason is a combination of issues concerning domestic and professional life that affects the ability to balance professional sports and studies. Students attempt to manage their academic life, sports and also enter the job market, all of which impact their achievements in professional sports (Verslandn, 2016).

The authors have developed a type of consultative agreement that stipulates that the best athletes receive additional motivation and stimulus. The cooperation is planned between Cēsis Sports School and University of Latvia. This collaboration would provide young athletes with the opportunity to continue pursuing professional sports until graduation.

\section{Discussion}

Development of dual careers can vary among countries. However, the European Parliament has named the three most important factors that should be considered by all EU Member States(Europien Guidelines, 2012). Firstly, mental and physical development of children that is balanced and planned, retaining the development of physical education. Training loads cannot be extensive and should be even. Another aspect is adhering to a healthy balance between academic studies and sports (Budeviča, 2018). According to the European guidelines, the focus should not shift in favour of either, for example, only achieving success in sports. A final point is made in regards to the end of athletes' careers. The transition from sports to a different career should be smooth and successful regardless of the amount of job experience (EU Guidelines...2012). Investigation of the aforementioned guidelines leads the authors to conclude that the dual career system in Latvia lacks development in the area of transitioning from professional sports to another career. Unfortunately, the authors have to conclude that there is no support system or programme in Latvia that would aid athletes in entering new careers.

In many European countries, such as, Norway, France, the Netherlands, the dual career system is highly developed (Kristiansen, 2017). Great Britain has created a support system for young athletes, The Talanted Athlete Schoralschip Scheme (TASS). It is a government funded institution that supports more than 300 young athletes representing 30 different types of sports (Talanted Athlete, 2014). The programme is intended for 
athletes aged 16 and above. It provides them with the possibility to receive education in secondary school or university alongside their career in professional sports. TASS cooperates with 24 higher education institutions across Great Britain. The athletes receive a scholarship in their chosen university, exemptions from tuition fees, medical services (specific for their chosen sports) as well as other provisions necessary for achieving outstanding results.

Director of TASS Guy Taylor indicates that this institution is the world's main brand that ensures cooperation between universities and development of dual careers. It is confirmed by their expertise and achievement. More than 6500 students have been part of this system and during their professional careers they have won more than 100 Olympic medals (Dual Career...2015).

The daily routine plays an important part for the students-athletes concerning their training schedules and academic studies (Geranisova, 2015). One research carried out in the EU about the routines of athletes show the variations among different countries. At the level of higher education, Latvia has the largest proportion of athletes that study and work full time amounting to 26\%. Whereas in Finland such athletes make up only $5 \%$ of the respondents. The proportion in Estonia is average, around 17\%. (Athletes Dual, 2013).

\section{Conclusions}

Youth development and general intelligence is dependent to a large extent on the functionality of the educational system. One of its main tasks is to promote a diverse outlook on life that is based on a healthy and physically active lifestyle.

- Mutual interest from sports schools and secondary schools is a prerequisite to establish the foundations for development of dual careers;

- The current situation in Latvian Northeast region Vidzeme can be considered satisfactory;

- Analysis of the responses of young athletes reveals that a dual career is regarded in a positive way by less than half of respondents. It refers to the statements relating to sports schools showing interest in the academic performance of students. When the statement includes a specific action for development of a dual career (for example, cooperation between secondary schools), most respondents reply negatively;

- Transition to sports in higher education institutions occurs without an established system, this is verified by most respondents; 
- The ability of educational institutions to adjust the daily routine of young athletes for sports and academic studies is a crucial aspect;

- Education for coaches is important in the field of dual careers;

- The cooperation agreement between Cēsis Sports School and Cēsis Secondary School is an example that proves the dual career system can be improved in a short time span;

- The other cooperation agreement between Cēsis Sports School and University of Latvia is currently a type of consultative agreement, however it is planned to be reviewed to render this cooperation functional.

\section{References}

Athletes Dual Career Survey 2012-2013. (2013) European Union. Pieejams:http://www. spordiinfo.ee/sportssociety/wp-content/uploads/2013/03/Dual + Career + Survey.pdf

Budeviča L. (2018). The Importance of Adopting National Policy Papers on Daul Career in the Field of Sport. University

Dual Career. More than a sport degree. (2014). Pieejams: http://enas-sport.net/wpcontent/uploads/2015/12/Taylor.pdf

Official journal of the European Union Conclusions of the council and of the representatives of the Member States meeting within the Council Sport dual career Eiropas Savienības Oficiālais Vēstnesis [anglsiki iztulkots]. (2013). Pieejams: https:// eur-lex.europa.eu/eli/reg/2013/1288/oj

Europien Guidelines on Dual Carrers of Athletes (2012). Recommended Policy Actions in Supports of Dual Carrers in Hihg-Performance Sport. Pieejams: http://ec.europa.eu/ assets/eac/sport/library/documents/dual-career-guidelines-final_en.pdf

Geranisova K. (2015). The expierence of dual career throught slovak athletes' eyes. Aarhu University, Denmark.

Golsorhi S. (2015) Strategy as Practise. Second Edition. Cambridge University

Kristiansen E. (2017). Developing Young Athletes: The role of private schools in Norwegian sport system. International Review of the Sociology of Sport, Norwegian School of Sport Sciences, Norway

Lī, M. (2017) A meta-synhesis of elites athletes expierience in dual career development, Routledge of sport Sociology, Asia Pacific Journal of Sport and Social Science

McKlave, J., Sincich. (2003). Statistics. NY Pearson Int. Edition, 3-th Edition

Sport law (2002). 1.Law article. [02.04.2018, 18.00]. Available: https://likumi.lv/doc. php?id $=68294$

The Talanted Athlete Scholarschip Scheme. (2014). Available: https://www.tass.gov.uk/ Versalnd, T. (2017). Exploring Self-Efficacy in Education Leadership Programs: What Makes the Difference? Journal of Leaderships Education. (page 50-56) 